\title{
Rule Of Law In Africa: The Role Of The Media In Civil Roceedings In Kenya.
}

\author{
Naomi Gichuki
}

\begin{abstract}
This article looks into the role of media and the public in civil proceedings in Kenya. The introductory component will address the concept of rule of law and its relevance to judicial independence and separation of powers. The second section of the article involves a critical analysis of the responsibility of the media as a check on government activities in its capacity as a pillar of society more commonly referred to as the 'fourth estate.' The role of the judiciary in a democratic society cannot be overlooked or undermined. For this reason, the article examines justice, society and media against the backdrop of a right to information, non-interference with judicial autonomy and access to justice. Pertinent challenges in the interplay of these three factors are discussed, followed by recommendations which propose effective channels through which the interaction between the public, media and judiciary in Kenya can become more meaningful.
\end{abstract}

\section{Introduction}

The $21^{\text {st }}$ century is awash with information. Technology has enabled enormous transformation in traditional media as we know it. Access to information is a constitutionally protected right, alongside media protection. The judiciary is generally perceived as the keeper of justice. The ultimate arbiter in disputes of every nature, ranging from criminal, to commercial, to civil disputes. This places an immense burden on the judiciary to remain independent in order to faithfully deliver on its expected role. Judicial independence can only thrive where rule of law is upheld. The judiciary is also responsible for accountability to the society. The media therefore plays a key role in highlighting judicial activities, as well as creating a vital connection between the courts and the people they serve.

\section{Rule of Law and Judicial Independence}

The concept of rule of law is important in the governance framework of any country and can certainly neither be overlooked nor ignored. This is primarily because the legal basis of any government is founded on the principle of legality, also referred to as rule of law. ${ }^{1}$

1 Halsbury's Laws of England, (2010). Constitutional Law and Human Rights (Volume 8(2) (Reissue) p 8, para 6(1.). 
Dicey $^{2}$ advanced three guidelines which, jointly, establish rule of law. These are; the absolute supremacy of regular law as opposed to arbitrary power, equality before the law and the law of the constitution being an outcome of rights defined and enforced by the courts. ${ }^{3}$

From this stems the conception that law has to be prescribed, courts and remedies have to be available to all people regardless of status or other discriminating factor, and the law as the source of substantive ideals that collectively form the rights available within the particular jurisdiction. This is primarily because the existence or otherwise of a power or duty is purely a function of law and not of fact. Capacities and legal personality are appropriated through the law, in the sense that public bodies are all created through statutory law. The parameters of the powers and duties to be exercised by these institutions are also a product of the law. ${ }^{4}$

Friedrich Hayek, in his work, envisaged rule of law as binding on government, through rules that were fixed and known before-hand. These rules should be crafted in such way that the manner in which coercive power is exercised by government machinery is certainly foreseeable. ${ }^{5}$ By so doing, individuals within such jurisdictions are better placed to plan their affairs, within the parameters of prescribed law. A similar view holds rule of law to mean that government officials and citizens are bound by and abide by the law. ${ }^{6}$ For this to be effective, it essentially requires that a system of law must be in place, in which the law is set out in advance and stated in general terms. It also requires that the law must be known and understood, that law must be equally applicable to all people governed by it, and that mechanisms for redress ought to be available in order to remedy any breach of legal rules. ${ }^{7}$

The United Nations defines Rule of Law as ${ }^{8}$

"A principle of governance in which all persons, institutions and entities, public and private, including the State itself, are accountable to laws that are publicly promulgated, equally enforced and independently adjudicated, and which are consistent with international human rights and standards. It requires, as well, measures to ensure adherence to the principles of supremacy of law, equality before the law, accountability to the law, fairness in the application of the law, separation of powers, participation in decision-making, legal certainty, avoidance of arbitration and procedural and legal transparency."

2 See Dicey. Law of the Constitution (10 ${ }^{\text {th }}$ Edn, 1959) $\mathrm{p} 187$.

3 Halsbury's $O p$ Cit note 1, at p 9.

4 Halsbury's. Constitutional Law and Human Rights (Volume 8(2) (Reissue) p 9, para 6(1.).

5 Fiedrich Hayek, (1945). The Road to Serfdom with the Intellectuals and Socialism. The Institute of Economic Affairs.

6 Tamanaha Brian, 2012. The History and Nature of Rule of Law. Singapore Journal of Legal Studies (2012), p 233.

7 Tamanaha, ibid.

8 United Nations Reports. The Rule of Law and Transitional Justice in Conflict and Post-Conflict Societies: Report of the Secretary-General. UN SC, UN Doc. S/2004/616, p 4. 
From the foregoing, it is evident that rule of law is an ideal relating to governance, or the exercise of public power. In addition to setting out parameters within which government power is exercised, it plays a fundamental role in relation to judicial independence. First, it requires that everybody who stands to be affected by a particular decision has the right to a meaningful day in court. ${ }^{9}$ Secondly, rule of law in relation to the judiciary requires that decisions emanating from the court rooms should not only be justifiable but should also be well-reasoned, while taking into account the circumstances to which the decision applies, as well as the demands of relevant principles applicable to the case. ${ }^{10}$

In addition, judicial officers should be independent, in every sense of the word- free from external influence by political and administrative superiors, and free from internal influence driven by personal interests such as bias, personal gain or partisan opinions. ${ }^{11}$ Independence should therefore be examined from these two perspectives. Independence will be absent if an individual judge is unable to make decisions without the fear or anticipation of illegitimate punishments or rewards. Further, the judiciary as an institution would only be considered as independent if it is able to properly and fully exercise its functions without depending on other government institutions or individuals in order to perform. ${ }^{12}$

Third is separation of powers, which is an element fundamental to any discussion on rule of law. In relation to judicial independence, it necessitates clear structural detachments in government structure, in such a way that the judiciary is able to hold other government structures answerable based on legal grounds. ${ }^{13}$ Institutional structures ought to protect the judiciary from interference by other arms of government. This is influenced primarily through the mode of appointment, which requires tht judges should be appointed based on their professional legal training and experience; security of tenure, which not only covers the duration of judges terms of office, but also the manner of removal from office; sufficient budgetary allocation to ensure that the court system functions as it should. This should also be reflected in the mode of remuneration established for judges. ${ }^{14}$

\section{Media as a Pillar of Society}

Media is derived from the word 'medium, ' which denotes the quality of being a carrier. Media also refers to an item that is specifically designed to reach a large audience. ${ }^{15}$ Throughout European history, media has traditionally been close both to the State and the capital.

9 John Ohnesorge, 2007. The Rule of Law. The Annual Review of Law and Social Science (2007), p 101.

10 John Ohnesorge, 2007. Ibid p 102.

11 Ibid,.

12 John Ferejohn, 1999. Independent Judges, Dependent Judiciary: Explaining Judicial Independence. Southern California Law Review [Vol 72] p 355.

13 Tamanaha Brian, 2012. Op cit note 6, p 240.

14 Ibid, $\mathrm{p} 244$.

15 Muhammad Nasir, 2013. Role of Media in a Developed Society. 
The advent and rise of democracy and political parties in the $20^{\text {th }}$ century saw media align itself with civil society, even though broadcasting largely remained a responsibility of the state. ${ }^{16}$

Tools of media in the current age are quite diverse, ranging from television, print media, radio, internet and social media. Mass media is useful for a variety of purposes including disseminating news and current affairs, education, and generating political awareness. Media is also largely viewed as the fourth element in a democratic society, based on Montesquieu's Separation of Powers. The traditional executive, judicial and parliamentary branches of government exist, while media adopts the role of independent journalism, a status specially facilitated by the existence of the right to freedom of information. ${ }^{17}$

In the same way that there exists different types of media in any society, the role of media is just as diverse. Media has a monitoring role, which entails reporting facts and issues objectively as a neutral observer. Media can also play a facilitative role, by providing citizens with a platform through which they can freely express themselves and participate in various political processes. Apart from this, media can also have a radical role in society, manifested through adoption of an oppositional approach toward the prevailing power. Such a role will often involve questioning socio-political order and inciting revolution. Finally, media can adopt a collaborative approach which entails serving government and other centres of power directly. ${ }^{18}$

\section{Judiciary and the Public}

The judicial system is largely construed to be the custodian of justice in most jurisdictions. Typically, the judiciary is expected to interpret legislation in line with the intentions of Parliament, and in certain legal systems such as that of common law, the judiciary plays the extra role of developing judge-made law, which comes about when...

In Kenya, judicial authority is derived from the people and vests in, and is exercised by, the courts and tribunals established by or under the Constitution. ${ }^{19}$ In exercising judicial authority, it is expected that the courts and tribunals are guided by the principles dictating that justice is done to all, irrespective of status, ${ }^{20}$ justice shall not be delayed ${ }^{21}$ alternative forms of dispute resolution including reconciliation, mediation, arbitration and traditional dispute

16 Kaarle Nordenstreng. Media and Society. Department of Journalism and Mass Communication, University of Tampere. Available on

http://www.uta.fi/jour/english/contact/nordenstreng_eng.html.

17 Ibid, $\mathrm{p} 2$.

18 Kaarle Nordenstreng. Ibid, p 4.

19 Constitution of Kenya, 2010. Article 159(1.).

20 Ibid, Article 159(2)(a.).

21 Article 159 (2)(b.). 
resolutions mechanisms are to be promoted, ${ }^{22}$ justice should be administered without undue regard to the procedural technicalities, ${ }^{23}$ and the promotion of the purpose and principles of the Constitution. ${ }^{24}$

Interaction between the judiciary, the public and the media calls for a facilitative framework that is able to deliver on the expectations of each of these groups. Currently, the Kenyan judiciary communicates with the public through its communication office, in addition to its various officials including the Chief Justice, the Deputy Chief Justice, Deputy Registrars of the High Court and Heads of Station, depending on the matter in question. Even though there is an official communication policy in place, it is still at the elementary stage and is therefore not fully implemented.

The public's interaction with the judiciary is anchored on the right to access to information. This right is constitutionally guaranteed through Article 35 which provides that every citizen has the right to information held by the State ${ }^{25}$ and information held by another person and required for the exercise or protection of any right or fundamental freedom. ${ }^{26}$ Further, every person has the right to the correction or deletion of untrue or misleading information that affects the person. ${ }^{27}$ The State is also required to publish and publicise any important information affecting the nation. ${ }^{28}$

\section{MEDIA AND JUDICIARY ${ }^{29}$}

The Kenyan media plays the key role of establishing a link between the judiciary and the public. To do this freely, media must operate in an environment where freedom of media is guaranteed. This right is established through Article 34 of the Constitution, which states that freedom and independence of electronic, print and all other types of media is guaranteed. ${ }^{30}$ This right however, does not extend to propaganda for war, incitement to violence, hate speech or advocacy of hatred that constitutes ethnic incitement, or based on any ground of discrimination. ${ }^{31}$

The State is prohibited from exercising control over or interference with any person engaged in broadcasting the production or circulation of any publication or the dissemination

22 Article 159 (2)(c.).

23 Article 159 (2)(d.).

24 Article 159 (2)(e.).

25 Article 35 1(a.).

26 Article 35 1(b.).

27 Article 35 (2.).

28 Article 35 (3.).

29 Findings set out in this section are the outcome of a discussion with Hon. Kennedy Kandet, Registrar of the High Court, on the role of the media in Civil Court Proceedings in Kenya.

30 Article 34 (1.).

31 Article 34 (1) read together with articles 33(2) and 27(4.). 
of information by any medium. ${ }^{32}$ The State is also required not to penalize any person for any opinion or view or content of any broadcast, publication or dissemination. ${ }^{33}$ Broadcasting and other electronic media have freedom of establishment, ${ }^{34}$ subject only to licensing procedures that are necessary to regulate the airwaves and other forms of signal distribution $^{35}$ and are independent of control by government, political interests or commercial interests. ${ }^{36}$ State-owned media is free to determine independently the editorial content of their broadcasts and other communications. ${ }^{37}$ State-owned media is also required to be impartial $^{38}$ and to afford fair opportunity for the presentation of divergent views and dissenting opinions. ${ }^{39}$

In Kenya, the media is allowed to record civil proceedings in all instances apart from matter involving minors or other matters that are considered to be of a highly sensitive nature. To a large extent, the media in Kenya has played a significant role in linking the public with the judiciary. This is evident through its efforts to publish judicial milestones, publish information on court procedures, informing the public on the progress in judicial infrastructure as well as keeping the public informed on judicial appointments including through broadcasting interviews during the process of appointing judges.

In this way, the media has had a significant impact in terms of boosting public confidence in the judiciary through showcasing service delivery (statistical summaries of matters filed, finalized, appealed on or ongoing). In addition to this, the media has facilitated access to information by publishing judgments and rulings, thereby contributing to informed decision making amongst members of the public. Closely related to this is the fact that media has played a key role in generating public awareness which enhances transparency and aids in informed participation especially with regard to holding government authorities accountable.

The media has been active in airing live court proceedings in cases where there is great public interest. Through this, the judiciary has also had the opportunity to assert its mandate and educate the public on its role in governance and other issues. Media participation has increased transparency by giving judiciary the opportunity to show the public that as an institution, it is not an obstacle to the timely delivery of justice, and that a lot of factors contribute to case adjournments and acquittals. This in turn instills confidence in members of the public, who are assured that their matters will be handled fairly and expeditiously. 
Despite the positive progress, it is not to say that there are no challenges with regard to the role of the media and the public in court proceedings in Kenya. For instance, there are instances when wrong information is disseminated, and this arises when proper information from the judiciary is not accessed on time, leading to speculative reporting. In other cases, judgments and rulings have been misreported, again attributed to delays in releasing official summarized judgments and rulings. Other notable challenges include misquoting judicial officers, media blackouts where the media completely fails to publicise important judicial activities because of mistreatment by the institution in the past, as well as crisis caused by leakage of sensitive information to media outlets through insiders in judicial institutions.

\section{RECOMMENDATIONS, CONCLUSION AND WAY FORWARD}

The relationship and interaction between the media, the public and the Kenyan judiciary has come a long way. That is not to say that the current status is the most ideal. A lot more can be done in order to enhance the role played by the three actors. First and foremost, there is need to develop more interactive forums between the judiciary and the media. Such forums would be useful in order to familiarize the media with judicial operations, as well as to familiarize the judiciary on the importance and role of media. In this way, misinformation and inaccurate or speculative reporting will be greatly reduced.

There is need to create better channels through which media outlets can assess accurate rulings and judgments from the judiciary. Implementation of the judiciary's communication policy should also be prioritized. This will enable relevant judicial officials to freely give information or comment on matters that touch on their dockets and professional views. It is also recommended that the judiciary appoint an official spokesperson whose roles would typically include; informing and instructing the press on matters of law and procedure; explaining to the public the nature and effect of judgments and rulings; furthering the interests of justice in promoting transparency and understanding of the court system by members of the public; following and reacting to media through websites and other social media as well as developing and maintaining liaisons and networks with appropriate professional bodies, specialists and academic and research institutions. 